\title{
Mending a broken heart: current strategies and limitations of cell-based therapy
}

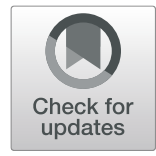

Lee Chuen Liew ${ }^{1}$, Beatrice Xuan Ho ${ }^{1,2}$ and Boon-Seng Soh ${ }^{1,2,3^{*}}$

\begin{abstract}
The versatility of pluripotent stem cells, attributable to their unlimited self-renewal capacity and plasticity, has sparked a considerable interest for potential application in regenerative medicine. Over the past decade, the concept of replenishing the lost cardiomyocytes, the crux of the matter in ischemic heart disease, with pluripotent stem cell-derived cardiomyocytes (PSC-CM) has been validated with promising pre-clinical results. Nevertheless, clinical translation was hemmed in by limitations such as immature cardiac properties, long-term engraftment, graft-associated arrhythmias, immunogenicity, and risk of tumorigenicity. The continuous progress of stem cell-based cardiac therapy, incorporated with tissue engineering strategies and delivery of cardio-protective exosomes, provides an optimistic outlook on the development of curative treatment for heart failure. This review provides an overview and current status of stem cell-based therapy for heart regeneration, with particular focus on the use of PSC-CM. In addition, we also highlight the associated challenges in clinical application and discuss the potential strategies in developing successful cardiac-regenerative therapy.
\end{abstract}

Keywords: Ischemic heart disease, Cell-based therapy, Pluripotent stem cells, Cardiomyocytes, Exosome

\section{Introduction}

Ischemic heart disease, the most common type of cardiovascular disease, is characterized by the restriction of blood flow to the heart muscle that results from the plaque build-up in the arteries [1]. This obstruction of coronary arteries limits the oxygen supply to the heart tissue and thus causes irreversible death of cardiomyocytes (myocardial infarction). As the disease progresses, especially if left untreated, the expansion of the infarcted zone will impair the function of the left ventricle, which would eventually lead to heart failure [2]. The current therapeutic options available, including pharmaceutical drugs, such as angiotensin-converting enzyme inhibitors, betablockers, diuretics, and angiotensin receptors blockers, are mainly symptomatic treatments that could merely alleviate

\footnotetext{
*Correspondence: bssoh@imcb.a-star.edu.sg

'Disease Modeling and Therapeutics Laboratory, A*STAR Institute of Molecular and Cell Biology, 61 Biopolis Drive Proteos, Singapore 138673, Singapore

${ }^{2}$ Department of Biological Sciences, National University of Singapore, Singapore 117543, Singapore

Full list of author information is available at the end of the article
}

the manifestation of the disease. Similarly, although cardiac revascularization therapy with percutaneous coronary intervention (PCI) and coronary artery bypass grafting (CABG), as well as the use of cardiac implantable electronic devices could improve the patient survival and quality of life, they have been ineffective in preventing the disease progression [3, 4]. While heart transplantation is thought to be the only curative treatment for patients with end-stage heart failure, the shortage of organ donors that limit the number of possible heart transplants and the associated post transplant complications makes this treatment inapplicable as yet.

Cardiovascular research has largely been focused on cell-based therapy for myocardial repair, with particular emphasis on replacement and/or restoration of the damaged myocardium [5, 6]. For the past two decades, immense efforts have been put into experimenting a myriad of transplantable cell types for their use in cardiac regeneration. These include skeletal myoblasts, bone marrow mononuclear cells (BM-MNC), hematopoietic stem cells (HSC), endothelial progenitor cells (EPC), mesenchymal 
stem cells (MSC), and pluripotent stem cell (PSC)-derived cardiomyocytes (CM) (PSC-CM) (Fig. 1). While seemingly favorable outcomes do come into view, no one ideal cell type has yet to emerge. This review aims to evaluate the existing state of cell-based therapy for heart disease, with a particular focus on PSC-CM. Herein, we also discuss the current translational challenges of PSC-CM and their future perspectives for successful cardiac regenerative therapy.

\section{Cell-based therapy}

Cardiomyocytes are terminally differentiated cells that lack regeneration potential, thereby limiting their ability to restore the cardiac function after serious injury $[7,8]$. In order to repair the myocardium, the most promising approach is to remuscularize the damaged tissue by replacing the lost cardiomyocytes, which could be done by transplantation of cells that are capable of cardiomyogenesis. Consequently, the search for the most suitable cell type for transplantation is therefore doubtlessly a crucial task. Table 1 summarized the cell types used for cardiac therapy and regeneration in pre-clinical and clinical studies.

\section{Adult stem cells}

Adult stem cells would probably be the first option that comes into one's mind, owing to their ability to develop into all cell types of the organ from which they originate and steer clear of the controversial ethical issue that has been haunting the use of embryonic stem cells. Skeletal myoblast, a precursor to adult skeletal myocyte, was the first cell type experimented for cardiac regeneration. Skeletal myoblasts were reported to regenerate functional skeletal muscle in response to injury [24, 25]. Owing to the ease of isolation, rapid in vitro expansion, and resistance to ischemia, they have been viewed as a potential candidate to remuscularize the injured heart [26]. Although most of the pre-clinical animal studies [27-32] and clinical studies [33, 34] of skeletal myoblasts have yielded promising results, many of the clinical trials were performed in conjunction with CABG or left ventricular assist device (LVAD) [35, 36], raising the ambiguity of the significant role of skeletal myoblasts in the therapy of heart failure. On the other hand, the therapeutic effects of transplanted BM-MNC in infarcted myocardium showed conflicting outcomes in animal studies. BM-MNC transplanted in a rat model [37] induced angiogenesis at the scar region and improved

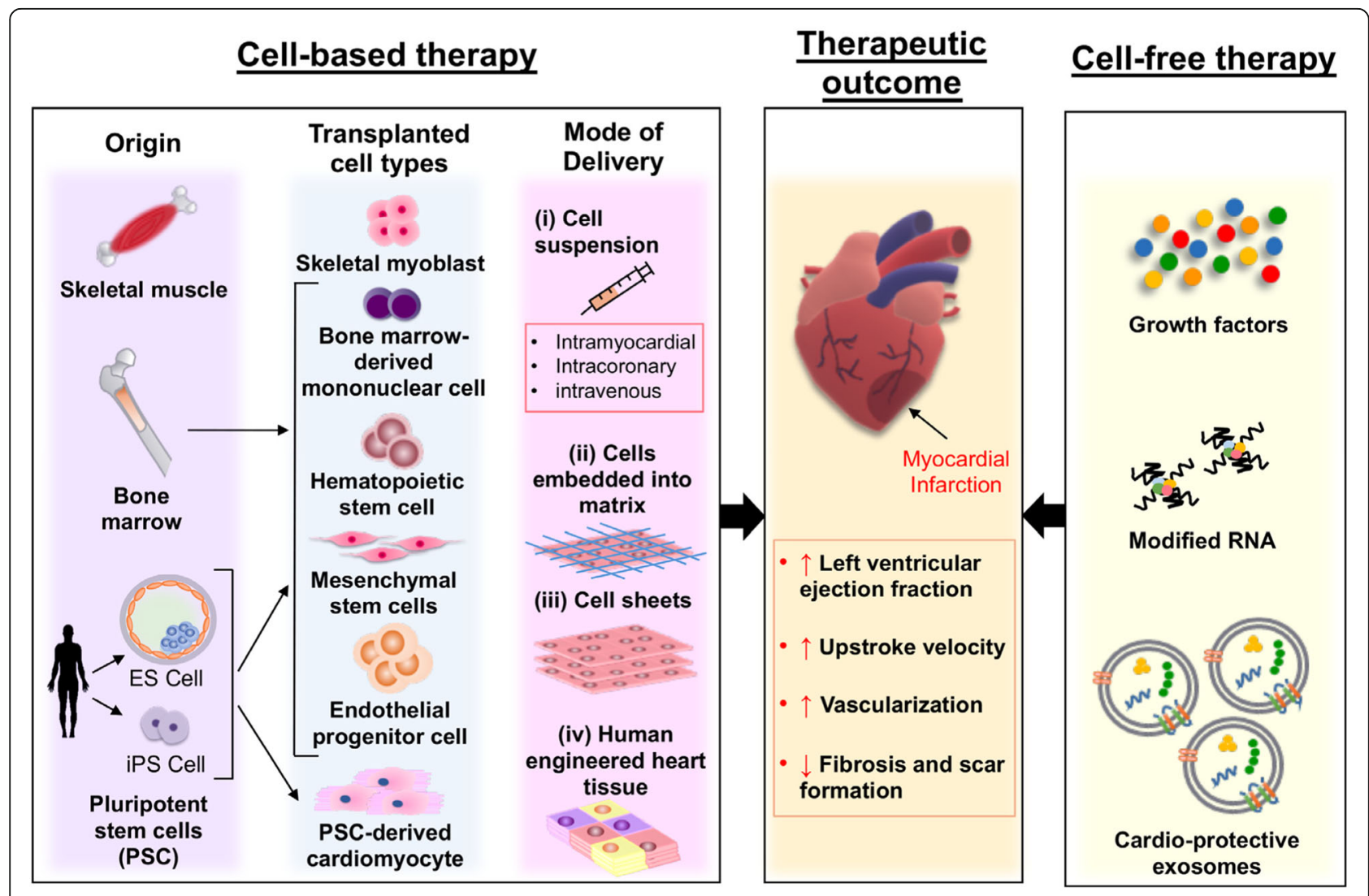

Fig. 1 Current strategies for successful cardiac regenerative therapy 
Table 1 Summary of different cell types and animal models used in cardiac repair and regeneration

\begin{tabular}{|c|c|c|c|c|c|}
\hline Cell types & & Model & Outcome & Mode of delivery & References \\
\hline \multirow[t]{7}{*}{$\begin{array}{l}\text { Pluripotent } \\
\text { stem cells }\end{array}$} & \multirow{2}{*}{$\begin{array}{l}\text { Human-induced pluripotent } \\
\text { stem cell-derived cardiomyo- } \\
\text { cytes (iPSC-CM) }\end{array}$} & Rat & $\begin{array}{l}\text { Improved cardiac function and } \\
\text { neovascularization }\end{array}$ & $\begin{array}{l}\text { Cell sheet transplantation at } \\
\text { myocardium }\end{array}$ & [9] \\
\hline & & Pig & $\begin{array}{l}\text { Increased ejection fraction and decreased } \\
\text { myocardial wall stress }\end{array}$ & $\begin{array}{l}\text { Cell sheet transplantation at } \\
\text { epicardial }\end{array}$ & [10] \\
\hline & \multirow{4}{*}{$\begin{array}{l}\text { Human embryonic stem cell- } \\
\text { derived cardiomyocytes (hESC- } \\
\text { CM) }\end{array}$} & Rat & Improved cardiac function & Injection in left ventricular wall & [11] \\
\hline & & Pig & Improved cardiac function & $\begin{array}{l}\text { Embryoid bodies } \\
\text { transplantation at } \\
\text { posterolateral wall of the left } \\
\text { ventricle }\end{array}$ & {$[12]$} \\
\hline & & $\begin{array}{l}\text { Non- } \\
\text { human } \\
\text { primates }\end{array}$ & Remuscularization of infarcted zone & Intramyocardial injection & [13] \\
\hline & & Mouse & Improved cardiac function & $\begin{array}{l}\text { Injected beneath the coronary } \\
\text { artery ligation }\end{array}$ & [14] \\
\hline & $\begin{array}{l}\text { Human embryonic stem cell- } \\
\text { derived cardiovascular } \\
\text { progenitors }\end{array}$ & Human & $\begin{array}{l}\text { Most patients were symptomatically } \\
\text { improved with an increased systolic motion } \\
\text { of the cell-treated segments }\end{array}$ & $\begin{array}{l}\text { Sub-epicardial injection of cells } \\
\text { in a fibrin patch }\end{array}$ & [15] \\
\hline \multirow{5}{*}{$\begin{array}{l}\text { Adult stem } \\
\text { cells }\end{array}$} & \multirow{2}{*}{$\begin{array}{l}\text { Bone marrow-derived mono- } \\
\text { nuclear cells (BM-MNC) and } \\
\text { progenitor cells }\end{array}$} & Human & Improved LVEF & Intracoronary infusion & {$[16-18]$} \\
\hline & & & No improvement of LVEF & & [19] \\
\hline & \multirow{2}{*}{$\begin{array}{l}\text { Bone marrow-derived mesen- } \\
\text { chymal stem cells (BM-MSC) }\end{array}$} & Human & Reduced infarct size and scar formation & Transendocardial injection & {$[20,21]$} \\
\hline & & Rat & Increased LVEF & $\begin{array}{l}\text { Epicardial placement of a } \\
\text { MSC-sheet }\end{array}$ & {$[22]$} \\
\hline & $\begin{array}{l}\text { Skeletal muscle-derived stem } \\
\text { cells }\end{array}$ & Human & Improved LVEF & Sub-epicardial injection & [23] \\
\hline
\end{tabular}

myocardial function, but no improvement in left ventricle function was observed in sheep [38] and porcine [39] models. The use of bone marrow-derived progenitor cells, such as HSC and EPC have also been studied in patients with both ischemic [40] and non-ischemic [41, 42] cardiomyopathies. The initial clinical results were encouraging but were disputable due to the small sample size. It is therefore unlikely to draw a definitive conclusion on the role of these cells in cardiac repair.

Of all the adult stem cell types, MSCs are in the center of attention for regenerative medicine. These multipotent stem cells were found to be readily available from various tissues and organs [43-48]. Studies have shown that MSCs are able to differentiate into several cell types [49-53] including functional cardiomyocytes in vitro $[54,55]$ and in vivo [56]. The emerging evidence on the homing potential of MSCs to the site of injury [57-59], coupled with their immunomodulatory properties, has made them more attractive for cardiac tissue repair. Several animal studies have reported the efficient engraftment and evidence of cardiomyogenesis of transplanted MSC at the host injury sites in myocardial infarction (MI) model [60, 61]. For instance, Quevedo et al. demonstrated that in the porcine model, injection of allogeneic male MSCs differentiated into myocyte, vascular muscle, and endothelial cells that integrated into female host myocardium. This was evident by the co- localization of the Y-chromosome with the trilineage markers [62]. Importantly, improvement in cardiac functions after MSC transplantation, as evidenced by the increased left ventricular ejection fraction (LVEF), myocardial blood flow (MBF), and contractility around the infarct border zone, was shown in the study. While extensive clinical trials that exploit MSC to repair the damaged myocardium are currently being conducted, both autologous and allogeneic MSC were generally reported to be safe and effective, except for one trial which showed no beneficial effect when MSCs were delivered through intravenous (IV) injection [63].

\section{Pluripotent stem cell-derived cardiomyocytes Human ES-derived cardiomyocytes}

Unlike adult stem cells, PSCs are highly expandable and can virtually differentiate into any adult somatic cell types, providing an unlimited source of cardiomyocytes. Numerous differentiation techniques have been developed to induce CMs from PSCs [64]. The initial differentiation method involved the embryoid body (EB) formation. EBs are spheroid aggregates that are able to differentiate into cells from all three germ layers within the three-dimensional structures [65]. Kehat and colleagues have demonstrated that human ESC-derived CMs can be isolated from spontaneously differentiated EB. However, this method has been reported to be 
inefficient and labor-intensive as only approximately $10 \%$ of the EBs exhibited spontaneous contractile characteristics and limited amount of CMs could be isolated by mechanical dissection from the beating areas [66]. As such, this EB-based method has then been supplanted by more refined methods that employ defined signaling factors and small molecules to manipulate nodal/activin, BMP4 [67, 68], and Wnt signaling [69, 70], which in turn promote cardiac mesodermal specification.

The feasibility and therapeutic efficacy of hPSC-CMs for cardiac repair after myocardial injury were tested on various animal models. Of note, one encouraging study revealed that the implanted hESC-derived CMs in slow heart-rate guinea pig model facilitated the repair of the infarcted heart and were able to achieve electrical integration with host myocardium [71]. Contradictorily, other researchers reported no significant improvement in cardiac function and limited electrical integration in chronic MI animal models following transplantation [72, 73]. Regardless of these mixed outcomes from the studies, the genuine therapeutic or side effect could be missed or overlooked as there are explicit differences between animal models and human. In order to achieve more precise evaluation of the therapeutic outcome and safety of using PSC-derived CMs in treating cardiac injury, a model with an electrical conduction system that closely resembles that of a human heart is therefore desirable. Accordingly, non-human primate models have been brought into play in various pre-clinical studies. Demonstrated by Chong et al., intramyocardial injection of hESC-CMs improved remuscularization of the infarcted heart in monkeys after ischemic reperfusion (I/R) injury, but complications associated with transient arrhythmia (abnormal heart rhythm) was observed in the study [13]. Another non-human primate MI model study, on the other hand, showed that transplanted human ESC-CMs improved LVEF, with only a subset of the animals experienced graft-associated arrhythmias [74]. The discrepancy in the risk of cardiac arrhythmias in the aforementioned studies was likely attributable to the difference in the disease model (I/R vs. MI), timing of cell delivery, the type, and dose of cardiomyocyte transplanted.

\section{iPSC-derived cardiomyocyte}

Since ESCs are derived from the inner cell mass of the blastocyst, its usage in research is therefore ethically controversial [75]. The discovery of induced pluripotent stem cell (iPSC) technology, a method of reprogramming somatic cells into pluripotent state using a cocktail of transcription factors, greatly opened up the new dimension of personalized medicine [76], as the use of patientspecific iPSCs to generate autologous grafts could circumvent the possible immune rejection and the ethical issue raised in human ESC. Accumulating evidence has shown that iPSCs display similar characteristics (surface markers, morphology, and growth properties) to that of ESCs $[77,78]$. This has spurred interest in investigating the cardiogenic potential of iPSCs [79, 80]. Indeed, iPSC-derived CMs exhibit functional properties of cardiac cells, such as spontaneous beating, contractility, and ion channel expression, suggesting that they can be regarded as a substitution to CMs derived from ESCs in restoring the damaged myocardium [81]. Kawamura et al. have reported that transplantation of hiPSCderived cardiomyocytes significantly improved LVEF and attenuated left ventricular remodeling in porcine MI model [82]. Whilst tremendous progress has been made in this field, the expectations of iPSC- and ESC-derived CMs have not been met and are yet to be ready for the application of cell therapy in heart failure.

\section{Translational challenges of PSC-CM in cell-based therapy} Immature phenotype

Despite the remarkable improvement in developing welldefined differentiation protocols to generate PSC-CM, the maturation status of these cells differs tremendously from that of the adult CMs. Of note, PSC-CMs display immature phenotypes that closely resemble fetal CMs. In terms of morphology, hPSC-CMs appeared to be round and mononucleated, in contrast to adult cardiomyocytes that were binucleated and rod-like in shape [83-85]. In addition, the contractile unit of sarcomeres in hPSC-CMs is shorter and less organized as compared to their mature counterpart. The immaturity of hPSC$\mathrm{CM}$ was also reflected by the absence of transverse tubules (T-tubules) [86, 87], inefficient contractility, difference in metabolism, and electrophysiological properties [88]. On top of the potential risk of arrhythmias upon transplantation, the lack of functional maturation in hPSC-CMs (as described in Table 2) results in inaccurate recapitulation of electrophysiological responses, thereby impeding its translation into clinical application.

With regard to this, many approaches that aim to enhance the maturation of hPSC-CMs in vitro have been sought and developed [106-109]. Prolonged culture [110], electrical stimulation [111-113], metabolic hormone [114-116], and ascorbic acid (AA) treatments [117] have been shown to induce a more mature phenotype of CMs with more organized sarcomere, improved contractile properties, and a shift in metabolism from anaerobic glycolysis towards oxidative phosphorylation [118]. Strategies including three-dimensional (3D) culture system that co-culture non-CMs and extracellular matrix (ECM) components [108], mechanical force imposed by cyclic stretch $[119,120]$, as well as microRNAs such as let-7 family, miR-499 and miR-1 [121, 122], were 
Table 2 A comparison between human PSC-derived fetal and adult cardiomyocytes

\begin{tabular}{|c|c|c|c|c|}
\hline & Characteristics & PSC-CM & Adult CM & References \\
\hline \multirow[t]{4}{*}{ Morphology } & Cell shape & Circular & Rod-shaped & [89-91] \\
\hline & Nucleation & Single nucleated & $25-30 \%$ binucleated & {$[92,93]$} \\
\hline & Mitochondrial content & $\begin{array}{l}\text { Slender and long, lesser than } \\
\text { in adult CM }\end{array}$ & $\begin{array}{l}\text { Elongated shape, } 35 \% \text { of total } \\
\text { cell volume }\end{array}$ & {$[94,95]$} \\
\hline & Surface area & $1000-1300 \mu m^{2}$ & $10,000-14,000 \mu m^{2}$ & {$[96,97]$} \\
\hline Metabolism & Substrate preference & Glucose & Fatty acid & {$[98,99]$} \\
\hline \multirow[t]{3}{*}{ Sarcomere } & $\begin{array}{l}\text { Myofibrillar isoform switch } \\
\text { (myosin heavy chain) }\end{array}$ & $\beta=a$ & $\beta>>a$ & [100-102] \\
\hline & Myofibril & Low density & High density & {$[83,91,103]$} \\
\hline & Alignment & Random & Anisotropic & {$[91,104]$} \\
\hline \multirow{2}{*}{$\begin{array}{l}\text { Electrophysiological } \\
\text { properties }\end{array}$} & Upstroke velocity & Slower & Faster & {$[83,97]$} \\
\hline & Contraction & Asynchronous & Synchronous & {$[98,105]$} \\
\hline
\end{tabular}

also employed to enhance the maturation process. Despite the emergence of these improved maturation protocols, a standard method to accurately evaluate the level of the maturation of PSC-derived CMs is yet to be defined. Recently, a group of researchers had identified a set of genes with identical relative expression orderings (REOs) within adult cardiac tissue but reversely identical in ESCs [123]. The authors utilized this list of genes to calculate the maturity score and measured the tendency of PSC-CM maturation by comparing the score to that of adult cardiomyocytes. Using this scoring system, they found that the maturity scores of PSC-CMs from 4 different culture methods were on the rise with the extension of culture time (up to 120 days) but were still not reaching the score of adult CM (0.7638 vs 0.9997$)$, suggesting that there is still a gap between mature-like PSC$\mathrm{CMs}$ and adult cardiomyocytes in the heart.

\section{Diverse cardiomyocyte subtypes (atrial, ventricular, and pacemaker cells)}

On top of the variable maturation status in hPSC-CMs, currently available differentiation protocols also generated heterogeneous cell populations that contained atrial, ventricular, and pacemaker cells [124-126]. Many have disregarded the importance of purifying specific cardiac subtypes for subsequent clinical testing, but transplantation of a heterogeneous pool of CM into an infarcted heart might affect the therapeutic outcomes. A detailed review reported that atrial, ventricular, and pacemaker cells possess different cardiac action potential (AP) due to the different roles they play in maintaining cardiac function [127]. The maximal upstroke velocity (Vmax) of ventricular cells is the highest $(200-300 \mathrm{~V} / \mathrm{s})$, followed by atrial cells $(200 \mathrm{~V} / \mathrm{s})$ and pacemaker cells (4-5 V/s). Another feature to distinguish different cardiac subtypes is the presence of spontaneous depolarization during phase 4 of the AP in nodal cells.
This spontaneous activity is extremely low in atrial cells and is completely absent in ventricular cells [127]. Hence, transplanting multiple subtypes of cardiac cells into the injured heart might lead to arrhythmias as they may not synchronize with the cardiac contractility in the host tissues.

In order to effectively treat the diseases that affect the specific regions of the heart, for example, to remuscularize the ventricular wall of the patient suffering from MI, the ideal approach would be to transplant the population of cells exclusively comprised of ventricular cardiomyocytes. Thus, various sorting and enrichment methods were developed to purify the chamber-specific cardiomyocytes from in vitro differentiated hPSC-CM. Zhang et al. (2011) demonstrated that the addition of retinoic acid (RA) to RALDH2+ mesoderm at the early stage of differentiation induced atrial-like cardiomyocytes at the expense of ventricular cells [128]. Contrarily, inhibition of canonical Wnt pathway by treatment with IWR-1 induced high yield of ventricular cardiomyocytes from hESC-derived cardiovascular progenitor cells [129]. Even with these improvements in chamber-specific cell purification, we are still far from generating a pure population of desired cardiac cell subtypes.

On the other hand, a stable transgenic hPSC line harboring fluorescent reporter under the transcriptional control of human myosin light chain-2V promoter (MLC2V) [130-132] and chick ovalbumin upstream promoter transcription factor II (COUP-TFII) [133] were developed to isolate ventricular and atrial cardiomyocytes, respectively. Despite the robust and high efficiency in enriching specific subtypes after cardiac differentiation of PSCs, the use of virus-based vector, again, has raised safety issues including immunogenicity and insertional mutagenesis risk that hinder their application in future clinical treatment. Among the handful publications about cell-type enrichment, none of the studies 
reported whether these cells bear resemblance to the right or left chambers of the heart. This could in turn represent another hitch as it was previously reported that the left and right ventricular cardiomyocytes are physiologically different and therefore might affect the outcome of cell therapy [134-136]. For example, owing to their responsibility to pump oxygenated blood to all parts of the body, left ventricular cardiomyocytes are particularly desired in the case of treating MI.

\section{Low engraftment rate of transplanted cells}

The poor survival and engraftment rate of transplanted cells are some of the major unresolved problems that constrain the efficacy of stem cell therapy in treating human diseases. This is due to the fact that transplanted cells are not capable of withstanding the ischemic environment at the site of the injury and the subsequent triggered immune response. Apart from that, the route of administration also affects the engraftment efficiency of hPSC-CM in the heart. Cells can be delivered to the injured myocardium through intramyocardial (IM), intracoronary (IC), or intravenous (IV) injections. Direct IM injection is the most common route of cell administration, but a substantial amount of cell leakage from the punctured holes after injection was reported. Besides, IM, performed through open-chest surgery, is also subjected to high-wall shear stress and acute inflammation [137]. In contrast, injection of cells into the coronary artery or the cardiac vein (IC injection) are mechanical less stressful than IM injection and showed minimal risk of injection-induced ventricular arrhythmias [138]. IV injection, on the other hand, appeared to be the least invasive mode of delivery but with extremely low cell retention as most of the transplanted cells were lost during their travel in the bloodstream and ended up being trapped in the lung, kidney, liver, and other organs [139-141]. Regardless of the route of delivery, engraftment of the transplanted cells to the infarcted myocardium is rare $(<2 \%)[142,143]$.

Several strategies to improve cell survival and engraftment are currently under investigation. In line with the advancement of biomaterial technology, hydrogel has emerged as one of the promising candidates for cardiac tissue engineering. This hydrophilic polymer could provide 3D structural support to the transplanted cell and enhance cell retention in the injured myocardium [144146]. Using a rat acute MI model, Christman et al. validated the effect of fibrin gel in improving the survival of transplanted cells and consequently the cardiac function. The infarct scar size of the rat injected with myoblastembedded in fibrin was significantly decreased after 5 weeks post transplantation as compared to the control group (myoblasts embedded with bovine serum albumin). Additionally, the use of fibrin promoted angiogenesis and arteriogenesis in the ischemic myocardium [145]. Other biomaterials, both natural (e.g., collagen, alginate) and synthetic (e.g., peptide nanofibers) were also shown to increase cell survival and stimulate tissue regeneration [147-149].

More recently, tissue engineering technology has also been widely explored for its applicability in cell-based tissue regeneration therapy. The creation of scaffold-free cell sheets, 3D-printed cardiac tissue with extracellular matrix (ECM) and human engineered heart tissue (hEHT), which can be implanted directly to the damaged myocardium has shed light in offering potential solution to the low cell viability and engraftment seen in cell suspension delivery methods $[150,151]$. Cell sheet is engineered by culturing the cells on a thermo-responsive polymer surface in monolayer or stacked into multilayers in order to preserved cell-to-cell connection and fabricated 3D cardiac tissues, followed by implantation into the damaged tissue. Transplantation of hiPSC-CM sheets at the myocardial infarct region in a porcine model of ischemic cardiomyopathy improved cardiac performance by structural and electromechanical integration into the host myocardium [82]. Another successful example of cell sheet technology in cardiac regeneration was demonstrated by Sekine et al., in which the author reported that cell sheet transplantation yielded greater cell survival over cell injection, with significant improvement in cardiac function and increased vascularization at the infarcted zone [152]. Using a multiphoton-excited 3D printing technology, hiPSCderived cardiac muscle patch (hCMP) consisting of hiPSC-CM and other cardiac cell types (hiPSC-EC and hiPCS-SMC) was also generated and evaluated in a mouse MI model. The animals showed improved cardiac functions, reduced infarct expansion, increased vascular density, and cell proliferation [153]. Additionally, transplanted hEHT derived from iPSC-CMs and human endothelial cells (hEC) also resulted in remuscularization of the scar heart tissue and promoted cardiac contractile function of guinea pig model [154]. While moderate success of engineered cardiac-like tissue has been achieved in myocardial repair of animal models, several problems arise. These include (i) short survival period of the transplanted tissue, (ii) ineffective integration to the host tissue resulting from insufficient vascularization, (iii) the need for open-chest surgery, (iv) risk of arrhythmia associated with large graft size, and (v) biodegradability of biomaterials used, all of which collectively hamper the success in clinical application.

\section{Teratoma formation and immune rejection}

Other concerns related to the clinical application of hPSC-derived cells include the risk of teratoma formation and immune rejection following transplantation. 
The presence of the residual undifferentiated hPSCs, resulting from inefficient differentiation of hPSCs and subsequent poor purification of terminally differentiated cell types, will potentially lead to tumorigenesis. Presently, there is no evidence of teratoma formation after transplantation of hPSC-derived CM into animal models [13, 71, 73, 155-157]. However, more in-depth studies that involve non-primate human models, generation of highly purified mature cardiomyocytes, and long-term follow-up post transplantation are certainly necessary to reassess the safety and efficacy of PSC-derived cell therapy. Moreover, karyotype instability caused by prolonged in vitro culture of PSCs remains a concern for potential neoplastic transformation $[158,159]$.

Given that most of the PSCs studies employed immunodeficient or immunosuppressed animals [13, 68, 71, 160], the possibility of PSC-based therapies in provoking unwanted immune reaction in clinical testing should not be disregarded. Whilst immunosuppressive therapy post transplantation could improve graft survival rate, undesirable complications such as increased risks associated with infection and malignancy are yet to be resolved [161]. Alternatively, the establishment of diverse human leukocyte antigen (HLA) typed PSC line has also been suggested to expand the number of target patients that can benefit from PSC-based cardiac therapy $[162,163]$.

\section{Alternative strategies for successful cardiac regeneration}

The concept of cardiac regeneration clings to the idea of repairing and/or replacing damaged cardiomyocytes. It was initially thought that the physical close proximity of PSC-CMs and their subsequent engraftment into the host tissue contributed to the functional recovery of MI in animal models. However, it has recently been suggested that the therapeutic efficacy of these transplanted cells could be executed by paracrine effects. This hypothesis stemmed from the findings that showed functional restoration of the injured murine myocardium despite suboptimal cell engraftment. Furthermore, the observation of abundant secretion of cardio-protective factors involved in antiapoptotic, pro-angiogenic, pro-cell proliferation, and $\mathrm{mi}-$ gration from PSC-CM to the host myocardium implied that the paracrine effects, rather than cell incorporation, could be accountable for the significant therapeutic impact seen in the in vivo studies $[164,165]$. Hence, this points towards the development of cell-free therapy that aims to stimulate the endogenous mechanism of regeneration in the heart (Fig. 1). Several innovative strategies have been proposed: (i) administration of cardiacprotective growth factors, (ii) overexpression of therapeutic proteins using modified RNA (modRNA), and (iii) delivery of extracellular vesicles harboring cardiac- regenerative biomolecules. A summary of these strategies are provided in Table 3.

\section{Growth factors}

Direct injection of cardiac-protective growth factors into the infarcted heart is the most straightforward way that offers immediate therapeutic effect and allows control over the administered dose. Therapeutic angiogenesis has been viewed as an effective approach in managing the disease as it could induce neovascularization that improves blood supply at the infarcted tissue. In line with this, most of the pre-clinical studies involving growth factor therapy for heart repair focused on vascular endothelial growth factor-A (VEGF) [184-187] and fibroblast growth factor (FGF) [188-190]. Porcine model of chronic myocardial ischemia treated with VEGF, either by IC delivery or direct epicardial implantation, showed significant improvement in the coronary flow [176]. Suppression of cardiomyocyte apoptosis is another strategy to alleviate ischemic injury in the cardiac tissue. Treatment with hepatocyte growth factor (HGF), an antiapoptotic factor, reduced apoptosis of cardiomyocytes and lesion size in rats [180]. Other anti-apoptotic factors such as platelet-derived growth factor (PDGF) [181] and interleukin (IL) $[182,183]$ have also been examined for their therapeutic potential in endogenous cardiac repair. Other potential alternatives to these approaches include induction of $\mathrm{CM}$ proliferation with acidic fibroblast growth factor (FGF-1) [177], neuregulin (NRG-1) [178], and periostin [179]. The aforementioned growth factors have demonstrated the safety and therapeutic efficacy in treating ischemic heart disease (IHD), particularly MI [191, 192]. However, the issues of short biological halflife, low specificity, and the need of repetitive injection to sustain therapeutic efficacy hamper its progress into clinical application.

\section{Modified mRNA}

On the other hand, endogenous cardiac repair can be achieved through the administration of messenger RNA (mRNA) encoding the protein of interest. Direct transfection of mRNA to the target cells enhances the translation of the desired therapeutic protein, but held back by low stability of mRNA and possible activation of the immune response. Several groups have shown that structural modification of RNA through the incorporation of 5-methylcytidine $(5 \mathrm{mC})$, pseudouridine $(\Psi), 5$ methyluridine $(5 \mathrm{mU})$, or N6-methyladenosine repressed Toll-like receptor (TLR) activation, thereby avoid triggering unwanted cellular immune response [193, 194]. Robust but transient expression of the encoded protein induced by modRNA could eradicate the risk of malignancy that would probably be caused by the prolonged expression of the delivered therapeutic molecules, a side 
Table 3 Summary of cell-free approaches used in cardiac repair

\begin{tabular}{|c|c|c|c|c|c|}
\hline \multicolumn{2}{|c|}{ Alternative strategies } & \multirow{2}{*}{$\frac{\text { Model }}{\text { Mouse }}$} & \multirow{2}{*}{$\begin{array}{l}\text { Outcome } \\
\text { Reduced infarct size }\end{array}$} & \multirow{2}{*}{$\begin{array}{l}\text { Type of disease } \\
\text { Myocardial infarction/ } \\
\text { reperfusion injury }\end{array}$} & \multirow{2}{*}{$\frac{\text { References }}{[166-168]}$} \\
\hline Exosomes & hESC-derived MSCs & & & & \\
\hline & $\begin{array}{l}\text { hESCSC-derived } \\
\text { cardiovascular progenitor }\end{array}$ & Mouse & $\begin{array}{l}\text { Reduced left ventricular end-systolic and end-diastolic } \\
\text { volumes }\end{array}$ & Chronic heart failure & [169] \\
\hline & $\begin{array}{l}\text { hiPSC-derived } \\
\text { cardiovascular progenitor }\end{array}$ & & $\begin{array}{l}\text { Improved cardiac function through decreased left ventricular } \\
\text { volumes and increased LVEF }\end{array}$ & Myocardial infarction & [170] \\
\hline & MSCs & Rat & Reduced apoptosis and the myocardial infarct size & Reperfusion injury & [171] \\
\hline \multirow{4}{*}{$\begin{array}{l}\text { Modified } \\
\text { mRNA }\end{array}$} & \multirow{3}{*}{$\begin{array}{l}\text { Vascular endothelial } \\
\text { growth factor (VEGF)-A }\end{array}$} & Mouse & Induced vascular regeneration & \multirow[t]{4}{*}{ Myocardial infarction } & [172] \\
\hline & & Pig & Improved LVEF, increased angiogenesis, and reduced fibrosis & & [173] \\
\hline & & Mouse & Promotes $|s| 1+$ to endothelial cell fate & & [174] \\
\hline & $\begin{array}{l}\text { Insulin-like growth factors } \\
\text { (IGFs) }\end{array}$ & Mouse & $\begin{array}{l}\text { Promote cardiomyocyte survival and abrogate cell apoptosis } \\
\text { post-Ml }\end{array}$ & & [175] \\
\hline \multirow[t]{8}{*}{$\begin{array}{l}\text { Growth } \\
\text { factors }\end{array}$} & VEGF & Pig & $\begin{array}{l}\text { Increased myocardial blood flow and improved regional } \\
\text { ventricular function }\end{array}$ & $\begin{array}{l}\text { Chronic myocardial } \\
\text { ischemia }\end{array}$ & [176] \\
\hline & $\begin{array}{l}\text { Fibroblast growth factors } \\
\text { (FGFs) }\end{array}$ & Mouse & Induced cardiomyocyte proliferation and division & Ischemic heart disease & [177] \\
\hline & Neuregulin 1 (NRG-1) & Mouse & $\begin{array}{l}\text { Induced cardiomyocyte proliferation and promotes } \\
\text { myocardial regeneration }\end{array}$ & Myocardial infarction & [178] \\
\hline & Periostin & Rat & Reduced fibrosis and infarct size, and increase angiogenesis & Myocardial infarction & [179] \\
\hline & $\begin{array}{l}\text { Hepatocyte growth } \\
\text { factor (HGF) }\end{array}$ & Rat & Reduced apoptosis of cardiomyocytes and lesion size & Reperfusion injury & [180] \\
\hline & $\begin{array}{l}\text { Platelet-derived growth } \\
\text { factor (PDGF) }\end{array}$ & Rat & $\begin{array}{l}\text { Decreased infarct size, decreased cardiomyocyte death, and } \\
\text { preserved systolic function }\end{array}$ & $\begin{array}{l}\text { Ischemia/reperfusiomy/ } \\
\text { myocardial infarction }\end{array}$ & [181] \\
\hline & \multirow[t]{2}{*}{$\begin{array}{l}\text { Interleukin (e.g., IL-33, IL- } \\
\text { 11) }\end{array}$} & Rat & $\begin{array}{l}\text { Reduced cardiomyocyte apoptosis, decreased infarct size and } \\
\text { fibrosis, and improved ventricular function }\end{array}$ & Ischemia/reperfusion & [182] \\
\hline & & Mouse & Reduced fibrosis and increase angiogenesis & Myocardial infarction & [183] \\
\hline
\end{tabular}

effect sometimes seen in conventional gene therapy [195]. A recent noteworthy study revealed that modRNA encoding human VEGF-A injected into the mice infarcted heart resulted in reduced infarct size, ameliorated myocardial perfusion, and improved survival [172]. Importantly, the authors uncovered the underlying mechanism, in which VEGF-A modRNA stimulated the proliferation of epicardial progenitors, followed by its migration to the injured myocardium and subsequent differentiation towards cardiovascular lineage. More recently, modRNAs encoding for IGF1, EGF, HGF, TGFb1, TGFb2, SDF-1, FGF-1, GH, and SCF have been widely investigated in cardiac cells and tissue [172, 174, 175, 196-198]. While most of these modRNAs showed certain level of therapeutic effects, more studies that aim to enhance transfection efficiency of the modRNA and the subsequent translation are fundamental in realizing their application in clinical therapy.

\section{Stem cell-derived exosomes as cell-free therapy in treating cardiovascular diseases}

The discovery of extracellular vesicle, in particular, exosome, as an important messenger in facilitating intercellular communication through transporting and transferring bioactive molecules (proteins and RNAs) between cells has opened a new perspective of applying cell-free therapy in cardiac regeneration [199]. Mouse ESC-derived exosomes have been shown to promote cardiac repair and preserve cardiac function in mouse MI model [200, 201]. In order to enhance the therapeutic effect of exosome in restoring the damaged heart, PSCs could also be genetically modified to secrete exosomes that are enriched with cardioprotective miRNAs, such as miR-21 and miR-210 [202-205]. Indeed, the proof-of-concept of exosome in delivering small RNA molecules to the targeted tissue has recently been confirmed by Alvarez-Erviti et al. [206]. More details about the role of exosome in cardiac regeneration were previously reviewed by $\mathrm{Ma}$ et al. [207]. Whilst PSC-derived exosomes offer an innovative approach in stimulating endogenous heart repair, the exact content in exosomes remains elusive. Such unidentified endogenous biomolecules in the exosomes might be transported to the recipient cells and lead to unknown side effects. An in-depth and rigorous characterization of its contents is therefore essential to ensure the safety of applying exosomes in cell-free therapy. 
Table 4 Comparison between cell-based and cell-free approaches for cardiac repair and regeneration

\begin{tabular}{|c|c|c|c|c|c|c|}
\hline & \multicolumn{3}{|c|}{ Cell-based therapy } & \multicolumn{3}{|l|}{ Cell-free therapy } \\
\hline & $\begin{array}{l}\text { Adult stem } \\
\text { cells }\end{array}$ & $\begin{array}{l}\text { Embryonic } \\
\text { stem cells }\end{array}$ & $\begin{array}{l}\text { Induced pluripotent } \\
\text { stem cells }\end{array}$ & Growth factors & Modified mRNA & Exosomes \\
\hline Origin & $\begin{array}{l}\text { Accessible in } \\
\text { various organs } \\
\text { and tissues }\end{array}$ & $\begin{array}{l}\text { Derived } \\
\text { from } \\
\text { embryos }\end{array}$ & $\begin{array}{l}\text { Derived from adult } \\
\text { somatic cells }\end{array}$ & - & - & Cell source dependent \\
\hline Ethical issues & No & Yes & No & \multicolumn{3}{|l|}{ No } \\
\hline $\begin{array}{l}\text { Genetics } \\
\text { stability }\end{array}$ & $\begin{array}{l}\text { Genetically } \\
\text { stable }\end{array}$ & \multicolumn{2}{|c|}{ Genetically unstable } & \multicolumn{3}{|l|}{-} \\
\hline Safety & $\begin{array}{l}\text { No evidence } \\
\text { for } \\
\text { tumorigenesis }\end{array}$ & \multicolumn{2}{|c|}{ Possible tumorigenic risk } & \multicolumn{3}{|l|}{ Non-tumorigenic } \\
\hline Immunogenicity & $\begin{array}{l}\text { Low risk of } \\
\text { immune } \\
\text { rejection }\end{array}$ & $\begin{array}{l}\text { Possible risk } \\
\text { of immune } \\
\text { rejection }\end{array}$ & $\begin{array}{l}\text { Possible risk of } \\
\text { immune rejection } \\
\text { (unless autologous) }\end{array}$ & $\begin{array}{l}\text { Non- } \\
\text { immunogenic }\end{array}$ & Non-immunogenic & $\begin{array}{l}\text { Depend on the nature of } \\
\text { donor cells }\end{array}$ \\
\hline $\begin{array}{l}\text { Risk of } \\
\text { arrhythmia }\end{array}$ & $\begin{array}{l}\text { Low risk of } \\
\text { arrhythmia }\end{array}$ & \multicolumn{2}{|c|}{ Possible risk of arrhythmia } & \multicolumn{3}{|c|}{ No evidence for risk of arrhythmia } \\
\hline $\begin{array}{l}\text { Factors } \\
\text { determining } \\
\text { therapeutic } \\
\text { efficacy }\end{array}$ & \multicolumn{3}{|c|}{$\begin{array}{l}\text { Highly dependent on the state of maturation, cell } \\
\text { number, and viability during transplantation }\end{array}$} & Loading dosage & $\begin{array}{l}\text { Protein expression } \\
\text { efficiency }\end{array}$ & $\begin{array}{l}\text { Content (biomolecules) in the } \\
\text { exosomes }\end{array}$ \\
\hline $\begin{array}{l}\text { Approach- } \\
\text { related } \\
\text { limitations }\end{array}$ & \multicolumn{3}{|c|}{$\begin{array}{l}\text { Large number of cells are required for significant } \\
\text { therapeutic effect }\end{array}$} & $\begin{array}{l}\text { Short biological } \\
\text { half-life and low } \\
\text { specificity }\end{array}$ & $\begin{array}{l}\text { May require multiple } \\
\text { injections due to } \\
\text { transient protein } \\
\text { expression }\end{array}$ & $\begin{array}{l}\text { Risk of unknown side effects } \\
\text { due to unidentified } \\
\text { biomolecules in the exosomes }\end{array}$ \\
\hline
\end{tabular}

\section{Conclusion}

The therapeutic potential of PSC-derived CM in cellbased therapy in terms of regenerating the damaged heart is evident by various successes in animal models. However, this seemingly promising therapeutic outcomes of PSC-derived CMs should not have overshined the unaddressed issues, particularly the immature phenotype and diverse cardiac cell subtypes that were generated during the differentiation from PSCs. Although many studies have been performed to develop defined differentiation and purification protocols for $\mathrm{CMs}$, it is still unclear to which extent the maturation of PSC-CMs would be ideal for optimal results. Other clinical hurdles, such as tumorigenicity, immunogenicity, and risk of arrhythmias, still remain to be resolved. We are well informed with the favorable and unfavorable impacts of PSC-CMs in animal models, but we know incredibly little about its implication in human. Further studies using humanized animal models are crucial in order to ensure precise prediction of human physiological responses and safety in clinical application. In addition, large-scale production of clinically compliant PSC-CMs is also required for translation into therapeutic reality. As such, stem cell-derived exosome that could possibly regenerate the damaged heart without the involvement of cells appears to be a potential approach to overcome the aforementioned problems of cell-based therapy. To achieve maximal therapeutic outcomes, factors (summarized in Table 4) may be considered in order to generate combinatorial therapies customizable to the severity and the types of heart disease. For instance, PSC-derived cardiac patch would be useful in replacing a large region of ventricular scar, whereas endogenous cardiac regeneration induced by MSCderived exosome cargo with cardio-protective factors could prevent disease progression.

\section{Abbreviations}

PSC-CM: Pluripotent stem cell-derived cardiomyocytes; PCI: Percutaneous coronary intervention; CABG: Coronary artery bypass grafting; BM-MNC: Bone marrow mononuclear cells; HSC: Hematopoietic stem cells; EPC: Endothelial progenitor cells; MSC: Mesenchymal stem cells; LVAD: Left ventricular assist device; LVEF: Left ventricular ejection fraction; MBF: Myocardial blood flow;

IV: Intravenous injection; EB: Embryoid body; IR: Ischemia reperfusion; iPSCs: Induced pluripotent stem cells; AA: Ascorbic acid; ECM: Extracellular matrix; REOs: Relative expression orderings; AP: Action potential; Vmax: Maximal upstroke velocity; RA: Retinoic acid; MI: Myocardial infarction; MLC2V: Myosin light chain-2V promoter; COUP-TFII: Chick ovalbumin upstream promoter transcription factor II; IM: Intramyocardial;

IC: Intracoronary; hEHT: Human engineered heart tissue; hCMP: hiPSC-derived cardiac muscle patch; HLA: Human leukocyte antigen; modRNAs: Modified RNA; VEGF: Vascular endothelial growth factor-A; FGF: Fibroblast growth factor; HGF: Hepatocyte growth factor; PDGF: Platelet-derived growth factor; IL: Interleukin; FGF-1: Fibroblast growth factor; NRG-1: Neuregulin; IHD: Ischemic heart diseases; mRNA: Messenger RNA; 5mC: 5-Methylcytidine; $\psi$ : Pseudouridine; 5mU: 5-Methyluridine; TLRs: Toll-like receptors

\section{Acknowledgements}

Publication fees were covered by the Institute of Molecular and Cell Biology, A*STAR. 


\section{Authors' contributions}

Liew L.C., Ho B.X., and Soh B.S. wrote the manuscript. All authors read and approved the final manuscript.

\section{Funding}

This work is supported by the Agency for Science, Technology and Research (Singapore) and by a grant from the National Medical Research Council to B.S.S (NMRC/OFYIRG/0017/2016). Beatrice Xuan Ho is supported by the National University of Singapore graduate scholarship.

\section{Availability of data and materials}

Not applicable

\section{Ethics approval and consent to participate}

Not applicable

\section{Consent for publication}

Not applicable

\section{Competing interests}

The authors declare that they have no competing interests.

\section{Author details}

'Disease Modeling and Therapeutics Laboratory, A*STAR Institute of Molecular and Cell Biology, 61 Biopolis Drive Proteos, Singapore 138673, Singapore. ${ }^{2}$ Department of Biological Sciences, National University of Singapore, Singapore 117543 , Singapore. ${ }^{3}$ Key Laboratory for Major Obstetric Diseases of Guangdong Province, The Third Affiliated Hospital of Guangzhou Medical University, Guangzhou 510150, China.

Received: 6 February 2020 Revised: 2 March 2020

Accepted: 10 March 2020 Published online: 26 March 2020

\section{References}

1. Writing Group M, Mozaffarian D, Benjamin EJ, Go AS, Arnett DK, Blaha MJ, et al. Heart disease and stroke statistics-2016 update: a report from the American Heart Association. Circulation. 2016;133(4):e38-360.

2. Pasumarthi KB, Field L. Cardiomyocyte cell cycle regulation. Circ Res. 2002; 90(10):1044-54.

3. Haqqani HM, Mond HG. The implantable cardioverter-defibrillator lead: principles, progress, and promises. Pacing Clin Electrophysiol. 2009;32(10): 1336-53.

4. Alba AC, Delgado DH. The future is here: ventricular assist devices for the failing heart. Expert Rev Cardiovasc Ther. 2009:7(9):1067-77.

5. Braunwald E. Cell-based therapy in cardiac regeneration: an overview. Circ Res. 2018;123(2):132-7.

6. Sun R, Li X, Liu M, Zeng Y, Chen S, Zhang P. Advances in stem cell therapy for cardiovascular disease (review). Int J Mol Med. 2016;38(1):23-9.

7. Eschenhagen T, Bolli R, Braun T, Field LJ, Fleischmann BK, Frisen J, et al. Cardiomyocyte regeneration: a consensus statement. Circulation. 2017; 136(7):680-6.

8. Bergmann O, Zdunek S, Felker A, Salehpour M, Alkass K, Bernard S, et al. Dynamics of cell generation and turnover in the human heart. Cell. 2015; 161(7):1566-75.

9. Masumoto $\mathrm{H}$, Ikuno $\mathrm{T}$, Takeda M, Fukushima $\mathrm{H}$, Marui $\mathrm{A}$, Katayama $\mathrm{S}$, et al, Human iPS cell-engineered cardiac tissue sheets with cardiomyocytes and vascular cells for cardiac regeneration. Sci Rep. 2014:4:6716.

10. Ishida M, Miyagawa S, Saito A, Fukushima S, Harada A, Ito E, et al. Transplantation of human-induced pluripotent stem cell-derived cardiomyocytes is superior to somatic stem cell therapy for restoring cardiac function and oxygen consumption in a porcine model of myocardial infarction. Transplantation. 2019;103(2):291-8.

11. Laflamme MA, Gold J, Xu C, Hassanipour M, Rosler E, Police S, et al. Formation of human myocardium in the rat heart from human embryonic stem cells. Am J Pathol. 2005;167(3):663-71.

12. Kehat I, Khimovich L, Caspi O, Gepstein A, Shofti R, Arbel G, et al. Electromechanical integration of cardiomyocytes derived from human embryonic stem cells. Nat Biotechnol. 2004;22(10):1282-9.

13. Chong JJ, Yang X, Don CW, Minami E, Liu YW, Weyers JJ, et al. Human embryonic-stem-cell-derived cardiomyocytes regenerate non-human primate hearts. Nature. 2014;510(7504):273-7.
14. Yu Y, Qin N, Lu XA, Li J, Han X, Ni X, et al. Human embryonic stem cellderived cardiomyocyte therapy in mouse permanent ischemia and ischemia-reperfusion models. Stem Cell Res Ther. 2019;10(1):167.

15. Menasche P, Vanneaux V, Hagege A, Bel A, Cholley B, Parouchev A, et al. Transplantation of human embryonic stem cell-derived cardiovascular progenitors for severe ischemic left ventricular dysfunction. J Am Coll Cardiol. 2018;71(4):429-38.

16. Assmus B, Schachinger $V$, Teupe $C$, Britten M, Lehmann R, Dobert $N$, et al. Transplantation of progenitor cells and regeneration enhancement in acute myocardial infarction (TOPCARE-AMI). Circulation. 2002;106(24):3009-17.

17. Strauer BE, Brehm M, Zeus T, Kostering M, Hernandez A, Sorg RV, et al. Repair of infarcted myocardium by autologous intracoronary mononuclear bone marrow cell transplantation in humans. Circulation. 2002;106(15):1913-8.

18. Leistner DM, Fischer-Rasokat U, Honold J, Seeger FH, Schachinger V, Lehmann $\mathrm{R}$, et al. Transplantation of progenitor cells and regeneration enhancement in acute myocardial infarction (TOPCARE-AMI): final 5-year results suggest long-term safety and efficacy. Clin Res Cardiol. 2011:100(10): 925-34.

19. Surder D, Manka R, Moccetti T, Lo Cicero V, Emmert MY, Klersy C, et al. Effect of bone marrow-derived mononuclear cell treatment, early or late after acute myocardial infarction: twelve months CMR and long-term clinical results. Circ Res. 2016;119(3):481-90.

20. Hare JM, Fishman JE, Gerstenblith G, DiFede Velazquez DL, Zambrano JP, Suncion WY, et al. Comparison of allogeneic vs autologous bone marrowderived mesenchymal stem cells delivered by transendocardial injection in patients with ischemic cardiomyopathy: the POSEIDON randomized trial. JAMA. 2012;308(22):2369-79.

21. Heldman AW, DiFede DL, Fishman JE, Zambrano JP, Trachtenberg BH, Karantalis $V$, et al. Transendocardial mesenchymal stem cells and mononuclear bone marrow cells for ischemic cardiomyopathy: the TAC-HFT randomized trial. JAMA. 2014;311(1):62-73.

22. Tano N, Narita T, Kaneko M, Ikebe C, Coppen SR, Campbell NG, et al. Epicardial placement of mesenchymal stromal cell-sheets for the treatment of ischemic cardiomyopathy: in vivo proof-of-concept study. Mol Ther. 2014, 22(10):1864-71.

23. Herreros J, Prosper F, Perez A, Gavira JJ, Garcia-Velloso MJ, Barba J, et al. Autologous intramyocardial injection of cultured skeletal muscle-derived stem cells in patients with non-acute myocardial infarction. Eur Heart J. 2003;24(22):2012-20.

24. Mauro A. Satellite cell of skeletal muscle fibers. J Biophys Biochem Cytol. 1961;9:493-5.

25. Buckingham M, Montarras D. Skeletal muscle stem cells. Curr Opin Genet Dev. 2008;18(4):330-6.

26. Chachques JC, Acar C, Herreros J, Trainini JC, Prosper F, D'Attellis N, et al. Cellular cardiomyoplasty: clinical application. Ann Thorac Surg. 2004;77(3): 1121-30.

27. Taylor DA, Atkins BZ, Hungspreugs $P$, Jones TR, Reedy MC, Hutcheson KA et al. Regenerating functional myocardium: improved performance after skeletal myoblast transplantation. Nat Med. 1998:4(8):929-33.

28. He KL, Yi GH, Sherman W, Zhou H, Zhang GP, Gu A, et al. Autologous skeletal myoblast transplantation improved hemodynamics and left ventricular function in chronic heart failure dogs. J Heart Lung Transplant. 2005:24(11):1940-9.

29. Fukushima S, Coppen SR, Lee J, Yamahara K, Felkin LE, Terracciano CM, et al. Choice of cell-delivery route for skeletal myoblast transplantation for treating post-infarction chronic heart failure in rat. PLoS One. 2008;3(8): e3071.

30. Farahmand P, Lai TY, Weisel RD, Fazel S, Yau T, Menasche P, et al. Skeletal myoblasts preserve remote matrix architecture and global function when implanted early or late after coronary ligation into infarcted or remote myocardium. Circulation. 2008;118(14 Suppl):S130-7

31. Gavira JJ, Perez-Ilzarbe M, Abizanda G, Garcia-Rodriguez A, Orbe J, Paramo $J A$, et al. A comparison between percutaneous and surgical transplantation of autologous skeletal myoblasts in a swine model of chronic myocardial infarction. Cardiovasc Res. 2006;71(4):744-53.

32. Chachques JC, Duarte F, Cattadori B, Shafy A, Lila N, Chatellier G, et al, Angiogenic growth factors and/or cellular therapy for myocardial regeneration: a comparative study. J Thorac Cardiovasc Surg. 2004;128(2): 245-53.

33. Menasche $P$, Hagege AA, Scorsin M, Pouzet B, Desnos M, Duboc D, et al. Myoblast transplantation for heart failure. Lancet. 2001;357(9252):279-80. 
34. Menasche P, Hagege AA, Vilquin JT, Desnos M, Abergel E, Pouzet B, et al. Autologous skeletal myoblast transplantation for severe postinfarction left ventricular dysfunction. J Am Coll Cardiol. 2003;41(7):1078-83.

35. Gavira JJ, Herreros J, Perez A, Garcia-Velloso MJ, Barba J, Martin-Herrero F, et al. Autologous skeletal myoblast transplantation in patients with nonacute myocardial infarction: 1-year follow-up. J Thorac Cardiovasc Surg. 2006;131(4):799-804

36. Dib N, Michler RE, Pagani FD, Wright S, Kereiakes DJ, Lengerich R, et al. Safety and feasibility of autologous myoblast transplantation in patients with ischemic cardiomyopathy: four-year follow-up. Circulation. 2005; 112(12):1748-55

37. Tomita S, Li RK, Weisel RD, Mickle DA, Kim EJ, Sakai T, et al. Autologous transplantation of bone marrow cells improves damaged heart function. Circulation. 1999;100(19 Suppl):II247-56.

38. Bel A, Messas E, Agbulut O, Richard P, Samuel JL, Bruneval P, et al. Transplantation of autologous fresh bone marrow into infarcted myocardium: a word of caution. Circulation. 2003;108(Suppl 1):I1247-52.

39. Waksman R, Fournadjiev J, Baffour R, Pakala R, Hellinga D, Leborgne L, et al. Transepicardial autologous bone marrow-derived mononuclear cell therapy in a porcine model of chronically infarcted myocardium. Cardiovasc Radiat Med. 2004;5(3):125-31.

40. Patel AN, Geffner L, Vina RF, Saslavsky J, Urschel HC Jr, Kormos R, et al. Surgical treatment for congestive heart failure with autologous adult stem cell transplantation: a prospective randomized study. J Thorac Cardiovasc Surg. 2005;130(6):1631-8.

41. Vrtovec B, Poglajen G, Sever M, Lezaic L, Domanovic D, Cernelc P, et al. Effects of intracoronary stem cell transplantation in patients with dilated cardiomyopathy. J Card Fail. 2011;17(4):272-81.

42. Vrtovec B, Poglajen G, Lezaic L, Sever M, Domanovic D, Cernelc P, et al. Effects of intracoronary CD34+ stem cell transplantation in nonischemic dilated cardiomyopathy patients: 5-year follow-up. Circ Res. 2013;112(1):165-73.

43. Zvaifler NJ, Marinova-Mutafchieva L, Adams G, Edwards CJ, Moss J, Burger $J A$, et al. Mesenchymal precursor cells in the blood of normal individuals. Arthritis Res. 2000;2(6):477-88.

44. Romanov YA, Svintsitskaya VA, Smirnov VN. Searching for alternative sources of postnatal human mesenchymal stem cells: candidate MSC-like cells from umbilical cord. Stem Cells. 2003;21(1):105-10.

45. Zuk PA, Zhu M, Ashjian P, De Ugarte DA, Huang Jl, Mizuno H, et al. Human adipose tissue is a source of multipotent stem cells. Mol Biol Cell. 2002; 13(12):4279-95.

46. In 't Anker PS, Scherjon SA, Kleijburg-van der Keur C, Noort WA, Claas FH, Willemze $\mathrm{R}$, et al. Amniotic fluid as a novel source of mesenchymal stem cells for therapeutic transplantation. Blood. 2003;102(4):1548-1549.

47. Fukuchi Y, Nakajima H, Sugiyama D, Hirose I, Kitamura T, Tsuji K. Human placenta-derived cells have mesenchymal stem/progenitor cell potential. Stem Cells. 2004;22(5):649-58.

48. Boyle AJ, McNiece IK, Hare JM. Mesenchymal stem cell therapy for cardiac repair. Methods Mol Biol. 2010;660:65-84.

49. Majumdar MK, Thiede MA, Haynesworth SE, Bruder SP, Gerson SL. Human marrow-derived mesenchymal stem cells (MSCS) express hematopoietic cytokines and support long-term hematopoiesis when differentiated toward stromal and osteogenic lineages. J Hematother Stem Cell Res. 2000;9(6): 841-8.

50. Ferrari G, Cusella-De Angelis G, Coletta M, Paolucci E, Stornaiuolo A, Cossu $G$, et al. Muscle regeneration by bone marrow-derived myogenic progenitors. Science. 1998;279(5356):1528-30.

51. Rodriguez LV, Alfonso Z, Zhang R, Leung J, Wu B, Ignarro LJ. Clonogenic multipotent stem cells in human adipose tissue differentiate into functional smooth muscle cells. Proc Natl Acad Sci U S A. 2006;103(32):12167-72.

52. Wosnitza M, Hemmrich K, Groger A, Graber S, Pallua N. Plasticity of human adipose stem cells to perform adipogenic and endothelial differentiation. Differentiation. 2007;75(1):12-23.

53. Sanchez-Ramos J, Song S, Cardozo-Pelaez F, Hazzi C, Stedeford T, Willing A, et al. Adult bone marrow stromal cells differentiate into neural cells in vitro. Exp Neurol. 2000;164(2):247-56.

54. Szaraz P, Gratch YS, labal F, Librach CL. In Vitro Differentiation of Human Mesenchymal Stem Cells into Functional Cardiomyocyte-like Cells. J Vis Exp. 2017:(126). https://doi.org/10.3791/55757.

55. Makino S, Fukuda K, Miyoshi S, Konishi F, Kodama H, Pan J, et al. Cardiomyocytes can be generated from marrow stromal cells in vitro. J Clin Invest. 1999;103(5):697-705.
56. Pei Z, Zeng J, Song Y, Gao Y, Wu R, Chen Y, et al. In vivo imaging to monitor differentiation and therapeutic effects of transplanted mesenchymal stem cells in myocardial infarction. Sci Rep. 2017;7(1):6296.

57. Chapel A, Bertho JM, Bensidhoum M, Fouillard L, Young RG, Frick J, et al. Mesenchymal stem cells home to injured tissues when co-infused with hematopoietic cells to treat a radiation-induced multi-organ failure syndrome. J Gene Med. 2003;5(12):1028-38.

58. Mouiseddine M, Francois S, Semont A, Sache A, Allenet B, Mathieu N, et al. Human mesenchymal stem cells home specifically to radiation-injured tissues in a non-obese diabetes/severe combined immunodeficiency mouse model. Br J Radiol 2007;80 Spec No 1:S49-S55.

59. Fong EL, Chan CK, Goodman SB. Stem cell homing in musculoskeletal injury. Biomaterials. 2011;32(2):395-409.

60. Toma C, Pittenger MF, Cahill KS, Byrne BJ, Kessler PD. Human mesenchymal stem cells differentiate to a cardiomyocyte phenotype in the adult murine heart. Circulation. 2002;105(1):93-8.

61. Hatzistergos KE, Quevedo H, Oskouei BN, Hu Q, Feigenbaum GS, Margitich IS, et al. Bone marrow mesenchymal stem cells stimulate cardiac stem cell proliferation and differentiation. Circ Res. 2010;107(7):913-22.

62. Quevedo HC, Hatzistergos KE, Oskouei BN, Feigenbaum GS, Rodriguez JE, Valdes D, et al. Allogeneic mesenchymal stem cells restore cardiac function in chronic ischemic cardiomyopathy via trilineage differentiating capacity. Proc Natl Acad Sci U S A. 2009;106(33):14022-7.

63. Chullikana A, Majumdar AS, Gottipamula S, Krishnamurthy S, Kumar AS, Prakash VS, et al. Randomized, double-blind, phase I/II study of intravenous allogeneic mesenchymal stromal cells in acute myocardial infarction. Cytotherapy. 2015;17(3):250-61.

64. Jiang $Y$, Lian XL. Heart regeneration with human pluripotent stem cells: prospects and challenges. Bioact Mater. 2020;5(1):74-81.

65. Pettinato $G$, Wen $X$, Zhang N. Formation of well-defined embryoid bodies from dissociated human induced pluripotent stem cells using microfabricated cell-repellent microwell arrays. Sci Rep. 2014:4:7402.

66. Kehat I, Kenyagin-Karsenti D, Snir M, Segev H, Amit M, Gepstein A, et al. Human embryonic stem cells can differentiate into myocytes with structural and functional properties of cardiomyocytes. J Clin Invest. 2001;108(3):407-14.

67. Yang L, Soonpaa MH, Adler ED, Roepke TK, Kattman SJ, Kennedy M, et al. Human cardiovascular progenitor cells develop from a KDR+ embryonicstem-cell-derived population. Nature. 2008;453(7194):524-8.

68. Laflamme MA, Chen KY, Naumova AV, Muskheli V, Fugate JA, Dupras SK, et al. Cardiomyocytes derived from human embryonic stem cells in prosurvival factors enhance function of infarcted rat hearts. Nat Biotechnol. 2007;25(9):1015-24

69. Lian X, Hsiao C, Wilson G, Zhu K, Hazeltine LB, Azarin SM, et al. Robust cardiomyocyte differentiation from human pluripotent stem cells via temporal modulation of canonical Wnt signaling. Proc Natl Acad Sci U S A. 2012;109(27):E1848-57.

70. Lian X, Zhang J, Azarin SM, Zhu K, Hazeltine LB, Bao X, et al. Directed cardiomyocyte differentiation from human pluripotent stem cells by modulating Wnt/beta-catenin signaling under fully defined conditions. Nat Protoc. 2013;8(1):162-75.

71. Shiba Y, Fernandes S, Zhu WZ, Filice D, Muskheli V, Kim J, et al. Human EScell-derived cardiomyocytes electrically couple and suppress arrhythmias in injured hearts. Nature. 2012;489(7415):322-5.

72. Fernandes S, Naumova AV, Zhu WZ, Laflamme MA, Gold J, Murry CE. Human embryonic stem cell-derived cardiomyocytes engraft but do not alter cardiac remodeling after chronic infarction in rats. J Mol Cell Cardiol. 2010;49(6):941-9.

73. Shiba Y, Filice D, Fernandes S, Minami E, Dupras SK, Biber BV, et al. Electrical integration of human embryonic stem cell-derived cardiomyocytes in a guinea pig chronic infarct model. J Cardiovasc Pharmacol Ther. 2014;19(4): 368-81.

74. Liu YW, Chen B, Yang X, Fugate JA, Kalucki FA, Futakuchi-Tsuchida A, et al. Human embryonic stem cell-derived cardiomyocytes restore function in infarcted hearts of non-human primates. Nat Biotechnol. 2018;36(7):597-605.

75. Thomson JA, Itskovitz-Eldor J, Shapiro SS, Waknitz MA, Swiergiel JJ, Marshall VS, et al. Embryonic stem cell lines derived from human blastocysts. Science. 1998;282(5391):1145-7.

76. Takahashi K, Yamanaka S. Induction of pluripotent stem cells from mouse embryonic and adult fibroblast cultures by defined factors. Cell. 2006;126(4): 663-76. 
77. Takahashi K, Tanabe K, Ohnuki M, Narita M, Ichisaka T, Tomoda K, et al. Induction of pluripotent stem cells from adult human fibroblasts by defined factors. Cell. 2007;131(5):861-72.

78. Yu J, Vodyanik MA, Smuga-Otto K, Antosiewicz-Bourget J, Frane JL, Tian S, et al. Induced pluripotent stem cell lines derived from human somatic cells. Science. 2007;318(5858):1917-20.

79. Mauritz C, Schwanke K, Reppel M, Neef S, Katsirntaki K, Maier LS, et al. Generation of functional murine cardiac myocytes from induced pluripotent stem cells. Circulation. 2008;118(5):507-17.

80. Zhang J, Wilson GF, Soerens AG, Koonce CH, Yu J, Palecek SP, et al. Functional cardiomyocytes derived from human induced pluripotent stem cells. Circ Res. 2009;104(4):e30-41.

81. Pfannkuche K, Liang H, Hannes T, Xi J, Fatima A, Nguemo F, et al. Cardiac myocytes derived from murine reprogrammed fibroblasts: intact hormonal regulation, cardiac ion channel expression and development of contractility. Cell Physiol Biochem. 2009;24(1-2):73-86.

82. Kawamura M, Miyagawa S, Miki K, Saito A, Fukushima S, Higuchi T, et al. Feasibility, safety, and therapeutic efficacy of human induced pluripotent stem cell-derived cardiomyocyte sheets in a porcine ischemic cardiomyopathy model. Circulation. 2012;126(11 Suppl 1):S29-37.

83. Mummery C, Ward-van Oostwaard D, Doevendans P, Spijker R, van den Brink S, Hassink R, et al. Differentiation of human embryonic stem cells to cardiomyocytes: role of coculture with visceral endoderm-like cells. Circulation. 2003;107(21):2733-40

84. Bird SD, Doevendans PA, van Rooijen MA, Brutel de la Riviere A, Hassink RJ, Passier $\mathrm{R}$, et al. The human adult cardiomyocyte phenotype. Cardiovasc Res 2003;58(2):423-434.

85. Snir M, Kehat I, Gepstein A, Coleman R, Itskovitz-Eldor J, Livne E, et al. Assessment of the ultrastructural and proliferative properties of human embryonic stem cell-derived cardiomyocytes. Am J Physiol Heart Circ Physiol. 2003;285(6):H2355-63.

86. Ziman AP, Gomez-Viquez NL, Bloch RJ, Lederer WJ. Excitation-contraction coupling changes during postnatal cardiac development. J Mol Cell Cardiol. 2010;48(2):379-86.

87. Lieu DK, Liu J, Siu CW, McNerney GP, Tse HF, Abu-Khalil A, et al. Absence of transverse tubules contributes to non-uniform $\mathrm{Ca}(2+)$ wavefronts in mouse and human embryonic stem cell-derived cardiomyocytes. Stem Cells Dev. 2009:18(10):1493-500.

88. Machiraju P, Greenway SC. Current methods for the maturation of induced pluripotent stem cell-derived cardiomyocytes. World J Stem Cells. 2019; 11(1):33-43.

89. Kim HD, Kim DJ, Lee IJ, Rah BJ, Sawa Y, Schaper J. Human fetal heart development after mid-term: morphometry and ultrastructural study. J Mol Cell Cardiol. 1992;24(9):949-65.

90. Veerman CC, Kosmidis G, Mummery CL, Casini S, Verkerk AO, Bellin M. Immaturity of human stem-cell-derived cardiomyocytes in culture: fatal flaw or soluble problem? Stem Cells Dev. 2015;24(9):1035-52.

91. Feric NT, Radisic M. Maturing human pluripotent stem cell-derived cardiomyocytes in human engineered cardiac tissues. Adv Drug Deliv Rev. 2016;96:110-34.

92. Olivetti G, Cigola E, Maestri R, Corradi D, Lagrasta C, Gambert SR, et al. Aging, cardiac hypertrophy and ischemic cardiomyopathy do not affect the proportion of mononucleated and multinucleated myocytes in the human heart. J Mol Cell Cardiol. 1996;28(7):1463-77.

93. Mollova M, Bersell K, Walsh S, Savla J, Das LT, Park SY, et al. Cardiomyocyte proliferation contributes to heart growth in young humans. Proc Natl Acad Sci U S A. 2013;110(4):1446-51.

94. Garcia-Perez C, Hajnoczky G, Csordas G. Physical coupling supports the local $\mathrm{Ca} 2+$ transfer between sarcoplasmic reticulum subdomains and the mitochondria in heart muscle. J Biol Chem. 2008;283(47):32771-80.

95. Piquereau J, Caffin F, Novotova M, Lemaire C, Veksler V, Garnier A, et al. Mitochondrial dynamics in the adult cardiomyocytes: which roles for a highly specialized cell? Front Physiol. 2013:4:102

96. Li Y, Shi X, Tian L, Sun H, Wu Y, Li X, et al. AuNP-collagen matrix with localized stiffness for cardiac-tissue engineering: enhancing the assembly of intercalated discs by beta1-integrin-mediated signaling. Adv Mater. 2016; 28(46):10230-5.

97. Ribeiro MC, Tertoolen LG, Guadix JA, Bellin M, Kosmidis G, D'Aniello C, et al. Functional maturation of human pluripotent stem cell derived cardiomyocytes in vitro--correlation between contraction force and electrophysiology. Biomaterials. 2015;51:138-50.
98. Keung W, Boheler KR, Li RA. Developmental cues for the maturation of metabolic, electrophysiological and calcium handling properties of human pluripotent stem cell-derived cardiomyocytes. Stem Cell Res Ther. 2014;5(1):17.

99. Lopaschuk GD, Jaswal JS. Energy metabolic phenotype of the cardiomyocyte during development, differentiation, and postnatal maturation. J Cardiovasc Pharmacol. 2010;56(2):130-40.

100. Razeghi P, Young ME, Alcorn JL, Moravec CS, Frazier OH, Taegtmeyer $\mathrm{H}$. Metabolic gene expression in fetal and failing human heart. Circulation. 2001;104(24):2923-31.

101. Siedner S, Kruger M, Schroeter M, Metzler D, Roell W, Fleischmann BK, et al. Developmental changes in contractility and sarcomeric proteins from the early embryonic to the adult stage in the mouse heart. J Physiol. 2003; 548(Pt 2):493-505

102. Xu XQ, Soo SY, Sun W, Zweigerdt R. Global expression profile of highly enriched cardiomyocytes derived from human embryonic stem cells. Stem Cells. 2009;27(9):2163-74.

103. Maillet M, van Berlo JH, Molkentin JD. Molecular basis of physiological heart growth: fundamental concepts and new players. Nat Rev Mol Cell Biol. 2013;14(1):38-48.

104. Gerdes AM, Kellerman SE, Moore JA, Muffly KE, Clark LC, Reaves PY, et al. Structural remodeling of cardiac myocytes in patients with ischemic cardiomyopathy. Circulation. 1992;86(2):426-30.

105. Liau B, Zhang D, Bursac N. Functional cardiac tissue engineering. Regen Med. 2012;7(2):187-206

106. Herron TJ, Rocha AM, Campbell KF, Ponce-Balbuena D, Willis BC, GuerreroSerna $\mathrm{G}$, et al. Extracellular matrix-mediated maturation of human pluripotent stem cell-derived cardiac monolayer structure and electrophysiological function. Circ Arrhythm Electrophysiol. 2016;9(4): e003638.

107. Ulmer BM, Stoehr A, Schulze ML, Patel S, Gucek M, Mannhardt I, et al. Contractile work contributes to maturation of energy metabolism in hiPSCderived cardiomyocytes. Stem Cell Reports. 2018;10(3):834-47.

108. Shadrin IY, Allen BW, Qian Y, Jackman CP, Carlson AL, Juhas ME, et al. Cardiopatch platform enables maturation and scale-up of human pluripotent stem cell-derived engineered heart tissues. Nat Commun. 2017; 8(1):1825.

109. Ronaldson-Bouchard K, Ma SP, Yeager K, Chen T, Song L, Sirabella D, et al. Advanced maturation of human cardiac tissue grown from pluripotent stem cells. Nature. 2018;556(7700):239-43.

110. Lundy SD, Zhu WZ, Regnier M, Laflamme MA. Structural and functional maturation of cardiomyocytes derived from human pluripotent stem cells. Stem Cells Dev. 2013;22(14):1991-2002.

111. Johnson TB, Kent RL, Bubolz BA, McDermott PJ. Electrical stimulation of contractile activity accelerates growth of cultured neonatal cardiocytes. Circ Res. 1994;74(3):448-59.

112. Kato S, Ivester CT, Cooper G, Zile MR, McDermott PJ. Growth effects of electrically stimulated contraction on adult feline cardiocytes in primary culture. Am J Phys. 1995:268(6 Pt 2):H2495-504.

113. Radisic M, Park H, Shing H, Consi T, Schoen FJ, Langer R, et al. Functional assembly of engineered myocardium by electrical stimulation of cardiac myocytes cultured on scaffolds. Proc Natl Acad Sci U S A. 2004;101(52): 18129-34.

114. Birket MJ, Ribeiro MC, Verkerk AO, Ward D, Leitoguinho AR, den Hartogh SC, et al. Expansion and patterning of cardiovascular progenitors derived from human pluripotent stem cells. Nat Biotechnol. 2015;33(9):970-9.

115. Yang $X$, Rodriguez $M$, Pabon $L$, Fischer KA, Reinecke $H$, Regnier $M$, et al. Triiodo-l-thyronine promotes the maturation of human cardiomyocytesderived from induced pluripotent stem cells. J Mol Cell Cardiol. 2014;72: 296-304.

116. Parikh SS, Blackwell DJ, Gomez-Hurtado N, Frisk M, Wang L, Kim K, et al. Thyroid and glucocorticoid hormones promote functional T-tubule development in human-induced pluripotent stem cell-derived cardiomyocytes. Circ Res. 2017;121(12):1323-30.

117. Cao N, Liu Z, Chen Z, Wang J, Chen T, Zhao X, et al. Ascorbic acid enhances the cardiac differentiation of induced pluripotent stem cells through promoting the proliferation of cardiac progenitor cells. Cell Res. 2012;22(1): 219-36.

118. Kerscher P, Bussie BS, DeSimone KM, Dunn DA, Lipke EA. Characterization of mitochondrial populations during stem cell differentiation. Methods $\mathrm{Mo}$ Biol. 2015;1264:453-63. 
119. Mihic A, Li J, Miyagi Y, Gagliardi M, Li SH, Zu J, et al. The effect of cyclic stretch on maturation and 3D tissue formation of human embryonic stem cell-derived cardiomyocytes. Biomaterials. 2014;35(9):2798-808.

120. Shimko VF, Claycomb WC. Effect of mechanical loading on threedimensional cultures of embryonic stem cell-derived cardiomyocytes. Tissue Eng Part A. 2008;14(1):49-58.

121. Kuppusamy KT, Jones DC, Sperber H, Madan A, Fischer KA, Rodriguez ML, et al. Let-7 family of microRNA is required for maturation and adult-like metabolism in stem cell-derived cardiomyocytes. Proc Natl Acad Sci U S A 2015;112(21):E2785-94.

122. Fu JD, Rushing SN, Lieu DK, Chan CW, Kong CW, Geng L, et al. Distinct roles of microRNA-1 and -499 in ventricular specification and functional maturation of human embryonic stem cell-derived cardiomyocytes. PLoS One. 2011;6(11):e27417.

123. Chen R, He J, Wang Y, Guo Y, Zhang J, Peng L, et al. Qualitative transcriptional signatures for evaluating the maturity degree of pluripotent stem cell-derived cardiomyocytes. Stem Cell Res Ther. 2019;10(1):113.

124. Moore JC, Fu J, Chan YC, Lin D, Tran H, Tse HF, et al. Distinct cardiogenic preferences of two human embryonic stem cell (hESC) lines are imprinted in their proteomes in the pluripotent state. Biochem Biophys Res Commun. 2008;372(4):553-8

125. He JQ, Ma Y, Lee Y, Thomson JA, Kamp TJ. Human embryonic stem cells develop into multiple types of cardiac myocytes: action potential characterization. Circ Res. 2003;93(1):32-9.

126. Zhang J, Klos M, Wilson GF, Herman AM, Lian X, Raval KK, et al. Extracellular matrix promotes highly efficient cardiac differentiation of human pluripotent stem cells: the matrix sandwich method. Circ Res. 2012;111(9): 1125-36.

127. Kane C, Terracciano CMN. Concise review: criteria for chamber-specific categorization of human cardiac myocytes derived from pluripotent stem cells. Stem Cells. 2017;35(8):1881-97.

128. Zhang Q, Jiang J, Han P, Yuan Q, Zhang J, Zhang X, et al. Direct differentiation of atrial and ventricular myocytes from human embryonic stem cells by alternating retinoid signals. Cell Res. 2011;21(4):579-87.

129. Karakikes I, Senyei GD, Hansen J, Kong CW, Azeloglu EU, Stillitano F, et al. Small molecule-mediated directed differentiation of human embryonic stem cells toward ventricular cardiomyocytes. Stem Cells Transl Med. 2014; 3(1):18-31.

130. Huber I, Itzhaki I, Caspi O, Arbel G, Tzukerman M, Gepstein A, et al. Identification and selection of cardiomyocytes during human embryonic stem cell differentiation. FASEB J. 2007;21(10):2551-63.

131. Li B, Yang H, Wang X, Zhan Y, Sheng W, Cai H, et al. Engineering human ventricular heart muscles based on a highly efficient system for purification of human pluripotent stem cell-derived ventricular cardiomyocytes. Stem Cell Res Ther. 2017;8(1):202

132. Yamauchi K, Li J, Morikawa K, Liu L, Shirayoshi Y, Nakatsuji N, et al. Isolation and characterization of ventricular-like cells derived from NKX2-5(eGFP/w) and MLC2v(mCherry/w) double knock-in human pluripotent stem cells. Biochem Biophys Res Commun. 2018;495(1):1278-84.

133. Schwach V, Verkerk AO, Mol M, Monshouwer-Kloots JJ, Devalla HD, Orlova W, et al. A COUP-TFIl human embryonic stem cell reporter line to identify and select atrial cardiomyocytes. Stem Cell Reports. 2017;9(6):1765-79.

134. Kondo RP, Dederko DA, Teutsch C, Chrast J, Catalucci D, Chien KR, et al. Comparison of contraction and calcium handling between right and left ventricular myocytes from adult mouse heart: a role for repolarization waveform. J Physiol. 2006;571(Pt 1):131-46.

135. Molina CE, Johnson DM, Mehel H, Spatjens RL, Mika D, Algalarrondo V, et al. Interventricular differences in beta-adrenergic responses in the canine heart: role of phosphodiesterases. J Am Heart Assoc. 2014;3(3):e000858.

136. Molina CE, Heijman J, Dobrev D. Differences in left versus right ventricular electrophysiological properties in cardiac dysfunction and arrhythmogenesis. Arrhythm Electrophysiol Rev. 2016;5(1):14-9.

137. Wollert KC, Drexler H. Clinical applications of stem cells for the heart. Circ Res. 2005:96(2):151-63.

138. Fukushima S, Varela-Carver A, Coppen SR, Yamahara K, Felkin LE, Lee J, et al. Direct intramyocardial but not intracoronary injection of bone marrow cells induces ventricular arrhythmias in a rat chronic ischemic heart failure model. Circulation. 2007;115(17):2254-61.

139. Brenner W, Aicher A, Eckey T, Massoudi S, Zuhayra M, Koehl U, et al. 111lnlabeled CD34+ hematopoietic progenitor cells in a rat myocardial infarction model. J Nucl Med. 2004;45(3):512-8.
140. Forest VF, Tirouvanziam AM, Perigaud C, Fernandes S, Fusellier MS, Desfontis $\mathrm{JC}$, et al. Cell distribution after intracoronary bone marrow stem cell delivery in damaged and undamaged myocardium: implications for clinical trials. Stem Cell Res Ther. 2010;1(1):4.

141. Aicher A, Brenner W, Zuhayra M, Badorff C, Massoudi S, Assmus B, et al. Assessment of the tissue distribution of transplanted human endothelial progenitor cells by radioactive labeling. Circulation. 2003;107(16):2134-9.

142. Zeng L, Hu Q, Wang X, Mansoor A, Lee J, Feygin J, et al. Bioenergetic and functional consequences of bone marrow-derived multipotent progenitor cell transplantation in hearts with postinfarction left ventricular remodeling. Circulation. 2007;115(14):1866-75.

143. Hong KU, Li QH, Guo Y, Patton NS, Moktar A, Bhatnagar A, et al. A highly sensitive and accurate method to quantify absolute numbers of c-kit+ cardiac stem cells following transplantation in mice. Basic Res Cardiol. 2013; 108(3):346.

144. Martens TP, Godier AF, Parks JJ, Wan LQ, Koeckert MS, Eng GM, et al. Percutaneous cell delivery into the heart using hydrogels polymerizing in situ. Cell Transplant. 2009;18(3):297-304.

145. Christman KL, Vardanian AJ, Fang Q, Sievers RE, Fok HH, Lee RJ. Injectable fibrin scaffold improves cell transplant survival, reduces infarct expansion, and induces neovasculature formation in ischemic myocardium. J Am Coll Cardiol. 2004;44(3):654-60.

146. Christman KL, Fok HH, Sievers RE, Fang Q, Lee RJ. Fibrin glue alone and skeletal myoblasts in a fibrin scaffold preserve cardiac function after myocardial infarction. Tissue Eng. 2004;10(3-4):403-9.

147. Segers VF, Lee RT. Biomaterials to enhance stem cell function in the heart. Circ Res. 2011;109(8):910-22.

148. Davis ME, Hsieh PC, Grodzinsky AJ, Lee RT. Custom design of the cardiac microenvironment with biomaterials. Circ Res. 2005;97(1):8-15.

149. Davis ME, Hsieh PC, Takahashi T, Song Q, Zhang S, Kamm RD, et al. Local myocardial insulin-like growth factor 1 (IGF-1) delivery with biotinylated peptide nanofibers improves cell therapy for myocardial infarction. Proc Natl Acad Sci U S A. 2006;103(21):8155-60

150. Riegler J, Tiburcy M, Ebert A, Tzatzalos E, Raaz U, Abilez OJ, et al. Human engineered heart muscles engraft and survive long term in a rodent myocardial infarction model. Circ Res. 2015;117(8):720-30.

151. Sawa Y, Yoshikawa Y, Toda K, Fukushima S, Yamazaki K, Ono M, et al. Safety and efficacy of autologous skeletal myoblast sheets (TCD-51073) for the treatment of severe chronic heart failure due to ischemic heart disease. Circ J. 2015;79(5):991-9.

152. Sekine H, Shimizu T, Dobashi I, Matsuura K, Hagiwara N, Takahashi M, et al. Cardiac cell sheet transplantation improves damaged heart function via superior cell survival in comparison with dissociated cell injection. Tissue Eng Part A. 2011;17(23-24):2973-80.

153. Gao L, Kupfer ME, Jung JP, Yang L, Zhang P, Da Sie Y, et al. Myocardial tissue engineering with cells derived from human-induced pluripotent stem cells and a native-like, high-resolution, 3-dimensionally printed scaffold. Circ Res. 2017;120(8):1318-25.

154. Weinberger F, Breckwoldt K, Pecha S, Kelly A, Geertz B, Starbatty J, et al. Cardiac repair in guinea pigs with human engineered heart tissue from induced pluripotent stem cells. Sci Transl Med. 2016;8(363):363ra148.

155. Caspi O, Huber I, Kehat I, Habib M, Arbel G, Gepstein A, et al. Transplantation of human embryonic stem cell-derived cardiomyocytes improves myocardial performance in infarcted rat hearts. J Am Coll Cardiol. 2007:50(19):1884-93.

156. van Laake LW, Passier R, Doevendans PA, Mummery CL. Human embryonic stem cell-derived cardiomyocytes and cardiac repair in rodents. Circ Res. 2008;102(9):1008-10.

157. Citro L, Naidu S, Hassan F, Kuppusamy ML, Kuppusamy P, Angelos MG, et al. Comparison of human induced pluripotent stem-cell derived cardiomyocytes with human mesenchymal stem cells following acute myocardial infarction. PLoS One. 2014;9(12):e116281.

158. Hartman ME, Dai DF, Laflamme MA. Human pluripotent stem cells: prospects and challenges as a source of cardiomyocytes for in vitro modeling and cell-based cardiac repair. Adv Drug Deliv Rev. 2016;96: 3-17.

159. Taapken SM, Nisler BS, Newton MA, Sampsell-Barron TL, Leonhard KA, McIntire EM, et al. Karotypic abnormalities in human induced pluripotent stem cells and embryonic stem cells. Nat Biotechnol. 2011;29(4):313-4.

160. van Laake LW, Passier R, Monshouwer-Kloots J, Verkleij AJ, Lips DJ, Freund C, et al. Human embryonic stem cell-derived cardiomyocytes survive and 
mature in the mouse heart and transiently improve function after myocardial infarction. Stem Cell Res. 2007;1(1):9-24.

161. Chinen J, Buckley RH. Transplantation immunology: solid organ and bone marrow. J Allergy Clin Immunol. 2010;125(2 Suppl 2):S324-35.

162. Taylor CJ, Bolton EM, Pocock S, Sharples LD, Pedersen RA, Bradley JA. Banking on human embryonic stem cells: estimating the number of donor cell lines needed for HLA matching. Lancet. 2005;366(9502):2019-25.

163. Nakajima F, Tokunaga K, Nakatsuji N. Human leukocyte antigen matching estimations in a hypothetical bank of human embryonic stem cell lines in the Japanese population for use in cell transplantation therapy. Stem Cells. 2007;25(4):983-5.

164. Tachibana A, Santoso MR, Mahmoudi M, Shukla P, Wang L, Bennett M, et al. Paracrine effects of the pluripotent stem cell-derived cardiac myocytes salvage the injured myocardium. Circ Res. 2017;121(6):e22-36.

165. Ong SG, Huber BC, Lee WH, Kodo K, Ebert AD, Ma Y, et al. Microfluidic single-cell analysis of transplanted human induced pluripotent stem cellderived cardiomyocytes after acute myocardial infarction. Circulation. 2015; 132(8):762-71.

166. Arslan F, Lai RC, Smeets MB, Akeroyd L, Choo A, Aguor EN, et al. Mesenchymal stem cell-derived exosomes increase ATP levels, decrease oxidative stress and activate PI3K/Akt pathway to enhance myocardial viability and prevent adverse remodeling after myocardial ischemia/ reperfusion injury. Stem Cell Res. 2013;10(3):301-12.

167. Lai RC, Arslan F, Lee MM, Sze NS, Choo A, Chen TS, et al. Exosome secreted by MSC reduces myocardial ischemia/reperfusion injury. Stem Cell Res. 2010;4(3):214-22.

168. Lai RC, Tan SS, Teh BJ, Sze SK, Arslan F, de Kleijn DP, et al. Proteolytic potential of the MSC exosome proteome: implications for an exosomemediated delivery of therapeutic proteasome. Int J Proteomics. 2012;2012: 971907

169. Kervadec A, Bellamy V, El Harane N, Arakelian L, Vanneaux V, Cacciapuoti I, et al. Cardiovascular progenitor-derived extracellular vesicles recapitulate the beneficial effects of their parent cells in the treatment of chronic heart failure. J Heart Lung Transplant. 2016;35(6):795-807.

170. El Harane N, Kervadec A, Bellamy V, Pidial L, Neametalla HJ, Perier MC, et al. Acellular therapeutic approach for heart failure: in vitro production of extracellular vesicles from human cardiovascular progenitors. Eur Heart J. 2018;39(20):1835-47.

171. Liu L, Jin X, Hu CF, Li R, Zhou Z, Shen CX. Exosomes derived from mesenchymal stem cells rescue myocardial ischaemia/reperfusion injury by inducing cardiomyocyte autophagy via AMPK and Akt pathways. Cell Physiol Biochem. 2017;43(1):52-68.

172. Zangi L, Lui KO, von Gise A, Ma Q, Ebina W, Ptaszek LM, et al. Modified mRNA directs the fate of heart progenitor cells and induces vascular regeneration after myocardial infarction. Nat Biotechnol. 2013;31(10):898-907.

173. Carlsson L, Clarke JC, Yen C, Gregoire F, Albery T, Billger M, et al. Biocompatible, purified VEGF-A mRNA improves cardiac function after intracardiac injection 1 week post-myocardial infarction in swine. Mol Ther Methods Clin Dev. 2018;9:330-46.

174. Lui KO, Zangi L, Silva EA, Bu L, Sahara M, Li RA, et al. Driving vascular endothelial cell fate of human multipotent $|s| 1+$ heart progenitors with VEGF modified mRNA. Cell Res. 2013;23(10):1172-86.

175. Huang $\mathrm{CL}$, Leblond AL, Turner EC, Kumar AH, Martin K, Whelan D, et al. Synthetic chemically modified mrna-based delivery of cytoprotective factor promotes early cardiomyocyte survival post-acute myocardial infarction. Mol Pharm. 2015;12(3):991-6.

176. Lopez JJ, Laham RJ, Stamler A, Pearlman JD, Bunting S, Kaplan A, et al. VEGF administration in chronic myocardial ischemia in pigs. Cardiovasc Res. 1998; 40(2):272-81.

177. Engel FB, Schebesta M, Duong MT, Lu G, Ren S, Madwed JB, et al. p38 MAP kinase inhibition enables proliferation of adult mammalian cardiomyocytes. Genes Dev. 2005;19(10):1175-87.

178. Bersell K, Arab S, Haring B, Kuhn B. Neuregulin1/ErbB4 signaling induces cardiomyocyte proliferation and repair of heart injury. Cell. 2009;138(2): 257-70.

179. Kuhn B, del Monte F, Hajjar RJ, Chang YS, Lebeche D, Arab S, et al. Periostin induces proliferation of differentiated cardiomyocytes and promotes cardiac repair. Nat Med. 2007;13(8):962-9.

180. Nakamura T, Mizuno S, Matsumoto K, Sawa Y, Matsuda H, Nakamura T. Myocardial protection from ischemia/reperfusion injury by endogenous and exogenous HGF. J Clin Invest. 2000;106(12):1511-9.
181. Hsieh PC, Davis ME, Gannon J, MacGillivray C, Lee RT. Controlled delivery of PDGF-BB for myocardial protection using injectable self-assembling peptide nanofibers. J Clin Invest. 2006;116(1):237-48.

182. Seki K, Sanada S, Kudinova AY, Steinhauser ML, Handa V, Gannon J, et al. Interleukin-33 prevents apoptosis and improves survival after experimental myocardial infarction through ST2 signaling. Circ Heart Fail. 2009;2(6):684-91.

183. Obana M, Maeda M, Takeda K, Hayama A, Mohri T, Yamashita T, et al. Therapeutic activation of signal transducer and activator of transcription 3 by interleukin-11 ameliorates cardiac fibrosis after myocardial infarction. Circulation. 2010;121(5):684-91.

184. Taimeh Z, Loughran J, Birks EJ, Bolli R. Vascular endothelial growth factor in heart failure. Nat Rev Cardiol. 2013;10(9):519-30.

185. Atluri P, Woo YJ. Pro-angiogenic cytokines as cardiovascular therapeutics: assessing the potential. BioDrugs. 2008:22(4):209-22.

186. Testa U, Pannitteri G, Condorelli GL. Vascular endothelial growth factors in cardiovascular medicine. J Cardiovasc Med (Hagerstown). 2008;9(12):1190-221.

187. Henry TD, Annex BH, McKendall GR, Azrin MA, Lopez JJ, Giordano FJ, et al. The VIVA trial: vascular endothelial growth factor in ischemia for vascular angiogenesis. Circulation. 2003;107(10):1359-65.

188. Zhang J, Li Y. Therapeutic uses of FGFs. Semin Cell Dev Biol. 2016;53:144-54

189. Unger EF, Goncalves L, Epstein SE, Chew EY, Trapnell CB, Cannon RO 3rd, et al. Effects of a single intracoronary injection of basic fibroblast growth factor in stable angina pectoris. Am J Cardiol. 2000;85(12):1414-9.

190. Simons M, Annex BH, Laham RJ, Kleiman N, Henry T, Dauerman H, et al. Pharmacological treatment of coronary artery disease with recombinant fibroblast growth factor-2: double-blind, randomized, controlled clinical trial. Circulation. 2002;105(7):788-93.

191. Formiga FR, Tamayo E, Simon-Yarza T, Pelacho B, Prosper F, Blanco-Prieto MJ. Angiogenic therapy for cardiac repair based on protein delivery systems. Heart Fail Rev. 2012;17(3):449-73.

192. Simon-Yarza T, Formiga FR, Tamayo E, Pelacho B, Prosper F, Blanco-Prieto MJ. Vascular endothelial growth factor-delivery systems for cardiac repair: an overview. Theranostics. 2012;2(6):541-52.

193. Sahin U, Kariko K, Tureci O. mRNA-based therapeutics--developing a new class of drugs. Nat Rev Drug Discov. 2014;13(10):759-80.

194. Patel S, Athirasala A, Menezes PP, Ashwanikumar N, Zou T, Sahay G, et al. Messenger RNA delivery for tissue engineering and regenerative medicine applications. Tissue Eng Part A. 2019;25(1-2):91-112.

195. Hadas Y, Katz MG, Bridges CR, Zangi L. Modified mRNA as a therapeutic tool to induce cardiac regeneration in ischemic heart disease. Wiley Interdiscip Rev Syst Biol Med. 2017;9(1). https://doi.org/10.1002/wsbm.1367.

196. Zangi L, Oliveira MS, Ye LY, Ma Q, Sultana N, Hadas Y, et al. Insulin-like growth factor 1 receptor-dependent pathway drives epicardial adipose tissue formation after myocardial injury. Circulation. 2017;135(1):59-72.

197. Kondrat J, Sultana N, Zangi L. Synthesis of modified mRNA for myocardial delivery. Methods Mol Biol. 2017;1521:127-38.

198. Turnbull IC, Eltoukhy AA, Fish KM, Nonnenmacher M, Ishikawa K, Chen J, et al. Myocardial delivery of lipidoid nanoparticle carrying modRNA induces rapid and transient expression. Mol Ther. 2016;24(1):66-75.

199. Valadi H, Ekstrom K, Bossios A, Sjostrand M, Lee JJ, Lotvall JO. Exosomemediated transfer of mRNAs and microRNAs is a novel mechanism of genetic exchange between cells. Nat Cell Biol. 2007;9(6):654-9.

200. Ibrahim AG, Cheng K, Marban E. Exosomes as critical agents of cardiac regeneration triggered by cell therapy. Stem Cell Reports. 2014;2(5):606-19.

201. Khan M, Nickoloff E, Abramova T, Johnson J, Verma SK, Krishnamurthy P, et al. Embryonic stem cell-derived exosomes promote endogenous repair mechanisms and enhance cardiac function following myocardial infarction. Circ Res. 2015;117(1):52-64.

202. Wang Y, Zhang L, Li Y, Chen L, Wang X, Guo W, et al. Exosomes/ microvesicles from induced pluripotent stem cells deliver cardioprotective miRNAs and prevent cardiomyocyte apoptosis in the ischemic myocardium. Int J Cardiol. 2015;192:61-9.

203. Zhu H, Fan GC. Role of microRNAs in the reperfused myocardium towards post-infarct remodelling. Cardiovasc Res. 2012;94(2):284-92.

204. Xiao J, Pan Y, Li XH, Yang XY, Feng YL, Tan HH, et al. Cardiac progenitor cell-derived exosomes prevent cardiomyocytes apoptosis through exosomal miR-21 by targeting PDCD4. Cell Death Dis. 2016;7(6):e2277.

205. Diao H, Liu B, Shi Y, Song C, Guo Z, Liu N, et al. MicroRNA-210 alleviates oxidative stress-associated cardiomyocyte apoptosis by regulating BNIP3. Biosci Biotechnol Biochem. 2017;81(9):1712-20. 
206. Alvarez-Erviti L, Seow Y, Yin H, Betts C, Lakhal S, Wood MJ. Delivery of siRNA to the mouse brain by systemic injection of targeted exosomes. Nat Biotechnol. 2011;29(4):341-5.

207. Ma Z, Wang Y, Li H. Applications of extracellular vesicles in tissue regeneration. Biomicrofluidics. 2020;14(1):011501.

\section{Publisher's Note}

Springer Nature remains neutral with regard to jurisdictional claims in published maps and institutional affiliations. 